NOTE

\title{
Cutaneous mycobacteriosis in a captive Amazonian manatee Trichechus inunguis
}

\author{
Laura Reisfeld ${ }^{1,2, *}$, Cássia Yumi Ikuta ${ }^{3}$, Laura Ippolito ${ }^{1}$, Bruna Silvatti ${ }^{1}$, \\ José Soares Ferreira Neto ${ }^{3}$, José Luiz Catão-Dias ${ }^{2}$, Fernando C. W. Rosas ${ }^{4}$, \\ José Anselmo D'Affonsêca Neto ${ }^{4}$, Vera M. F. da Silva ${ }^{4}$ \\ ${ }^{1}$ Aquário de São Paulo, São Paulo, São Paulo 04275-000, Brazil \\ ${ }^{2}$ Laboratório de Patologia Comparada de Animais Selvagens (LAPCOM), Depto de Patologia (VPT),
} Faculdade de Medicina Veterinária e Zootecnia (FMVZ), Universidade de São Paulo (USP), São Paulo 05508-270, Brazil

${ }^{3}$ Laboratorio de Zoonoses Bacterianas (LZB), Depto Medicina Veterinária Preventiva e Saúde Animal (VPS), FMVZ/USP, São Paulo 05508-270, Brazil

${ }^{4}$ Laboratório de Mamíferos Aquáticos (LMA), Instituto Nacional de Pesquisas da Amazônia (INPA), Amazonas 69060-001, Brazil

\begin{abstract}
An adult male Amazonian manatee Trichechus inunguis under human care presented with 3 circular cutaneous lesions on the dorsal aspect of the rostrum and between the nostrils (plenum). Initially these lesions were superficial, hypopigmented, without warmth and non-painful. Microbiological cultures of skin swabs isolated Candida sp. and Pseudomonas aeruginosa, and topical treatment with antiseptic, antifungal, anti-inflammatory and antibiotic medication was instituted. This treatment strategy did not lead to any clinical improvement, and after $6 \mathrm{mo}$ the lesions progressed to a confluent abscess $(5.0 \times 3.0 \mathrm{~cm})$ with increased temperature and obvious discomfort on palpation. An impression smear of a cutaneous biopsy was submitted for ZiehlNeelsen staining and after detection of acid-fast bacilli, the cutaneous biopsy and a swab from the lesion were sent for histopathology, culture and sensitivity testing. After $5 \mathrm{~d}$ of incubation and through PCR-restriction analysis of the isolates, Mycobacterium fortuitum and M. abscessus were identified. Sensitivity testing indicated that the isolates were susceptible to ciprofloxacin and clarithromycin, and after draining of the lesion and administration of systemic antibiotic treatment, there was rapid clinical improvement. This report describes non-healing lesions in an aquatic animal and illustrates the importance of evaluating the presence of non-tuberculous mycobacteria, opportunistic pathogens which are ubiquitous in the aquatic environment, in protracted, nonresponsive cases. We also highlight the importance of a correct diagnosis and treatment approach, and we review concerns that these bacteria are zoonotic agents and are frequently resistant to conventional antibiotics.
\end{abstract}

KEY WORDS: Aquatic mammal $\cdot$ Zoonotic $\cdot$ Skin disease $\cdot$ Mycobacterium $\cdot$ Mycobacterium abscessus $\cdot$ Mycobacterium fortuitum

\section{INTRODUCTION}

The Amazonian manatee Trichechus inunguis is an aquatic mammal, endemic to the Amazon River Basin. It is the smallest and the only exclusively freshwater sirenian (Rosas 1994). This species is classified as Vulnerable on the Red List of the IUCN (2016) and in the Red Book of the Endangered Brazilian Species (Silva et al. 2008). Among sirenians, most mortalities can be attributed to human 
interactions, predation (Silva et al. 2011) and trauma (Lightsey et al. 2006). Although little information is available concerning the health of Amazonian manatees, bacterial diseases are significant contributors to morbidity and mortality in both wild and captive Antillean manatees (Silva et al. 2017) and dugongs (Nielsen et al. 2013). In these species, the skin is substantially thickened with reduced sloughing (Sokolov 1982), which may allow several microorganisms to colonize and persist for extended periods of time (Nielsen et al. 2013). Most isolated bacteria are part of the normal microbiome and may be opportunistic invaders. As a result, these microbes cannot be considered responsible for every disorder (Nielsen et al. 2013).

The genus Mycobacterium comprises strictly pathogenic species, such as those belonging to the $M$. tuberculosis complex and M. leprae, as well as opportunistic pathogens and saprophytic species, referred to as nontuberculous mycobacteria (NTMs). NTMs are ubiquitous in the environment (Bercovier \& Vincent 2001) and have been recovered from freshwater, seawater, wastewater and drinking water samples (HallStoodley et al. 1998). A growing number of NTMs have been reported as atypical pathogenic mycobacteria (September et al. 2004) capable of causing granulomatous and pyogranulomatous skin lesions in a wide variety of mammals, reptiles, amphibians and fish (Bercovier \& Vincent 2001).

Here we report the isolation of $M$. abscessus and $M$. fortuitum from a cutaneous lesion in a captive Amazonian manatee and the importance of a precise diagnosis, mycobacterial speciation and correct treatment approach.

\section{CASE REPORT}

A 10 yr old, $168 \mathrm{~kg}$ adult male Amazonian manatee was originally rescued at 2 mo of age, and has since been maintained in a freshwater tank with a variety of Amazonian fish species, including arapaima Arapaima gigas, tambaqui Colossoma macropomum, redtail catfish Phractocephalus hemioliopterus and paulicea catfish Paulicea luetkeni. The tank was wellwater supplied, with ultraviolet sterilization, sand and biological filtration and ozonation. To prevent accumulation of organic matter, solid filters were treated with chlorine for up to $48 \mathrm{~h}$ and with partial water exchanges and backwashes. Chlorine testing was routinely performed on filtered water, before it reached the tank where the animal was kept. Additionally, ozone levels in the water were always moni- tored to avoid high levels, which may damage the animal's skin. Water quality was checked daily and coliform counts were performed weekly.

At the end of November 2011, we observed 3 well delineated, circular skin lesions on the dorsal aspect of the rostrum (Fig. 1a). The lesions were superficial erosions with central pallor, raised margins and no perceptible heat, and they did not evoke discomfort on palpation. After disinfection of the area with $2 \%$ chlorhexidine solution, swab samples (Global Swab ${ }^{\circledR}$, Jiangsu Kangiian Medical Apparatus) were collected and submitted for fungal and bacterial culture. From these initial samples, no significant growth was recovered, and blood work, which included a complete blood count and chemistry panel, was unremarkable (Lazzarini et al. 2014). Prime differentials for the observed lesions included trauma, possibly related to fish bite or face rubbing in the exhibit. No infection was suspected at the time, and the lesions were considered simple bruises. Topical treatment with dexamethasone, neomycin sulfate, bacitracin zinc, griseofulvin and benzocaine (CREMA $6 \mathrm{~A}^{\circledR}$, Labyes), and retinyl acetate, amino acids, methionine and chloramphenicol (Epitezan ${ }^{\circledR}$, Allergan) was applied daily for 4 mo to assist with lesion resolution and prevent secondary infections. For these procedures, the animal was transferred to a smaller tank that could be easily drained. The topical treatment was applied after the area was disinfected with saline solution and $2 \%$ chlorhexidine solution, and within $15 \mathrm{~min}$, the animal was released back to the water. After 1 mo of treatment, there was slight improvement of the lesions, characterized by contracture of the wound margin, but the healing process was slow.

After 4 mo (March 2012), wound persistence (Fig. 1b) and a positive fungal culture for Candida sp. prompted a treatment shift to nystatin associated with zinc oxide, allantoin associated with zinc oxide (Alantol ${ }^{\circledR}$, Vetnil) and ciprofloxacin ointment (Ciloxan ${ }^{\circledR}$, Alcon). A blood sample was collected at this time, and clinical chemistry and hematology results were within the normal range for this species. As expected with wound persistence, there was an increased white blood cell (WBC) count, at the high end of normal (10900 cells $\mu^{-1}$ ), which was a significant change when compared to what was observed in previous exams, and discrete lymphocytosis (Table 1) (Lazzarini et al. 2014). One week later, the size and general aspect of the skin lesions suggested a degree of improvement.

Six months after the initial observations (September 2012), the skin lesions abscessed $(5.0 \times 3.0 \mathrm{~cm}$; 

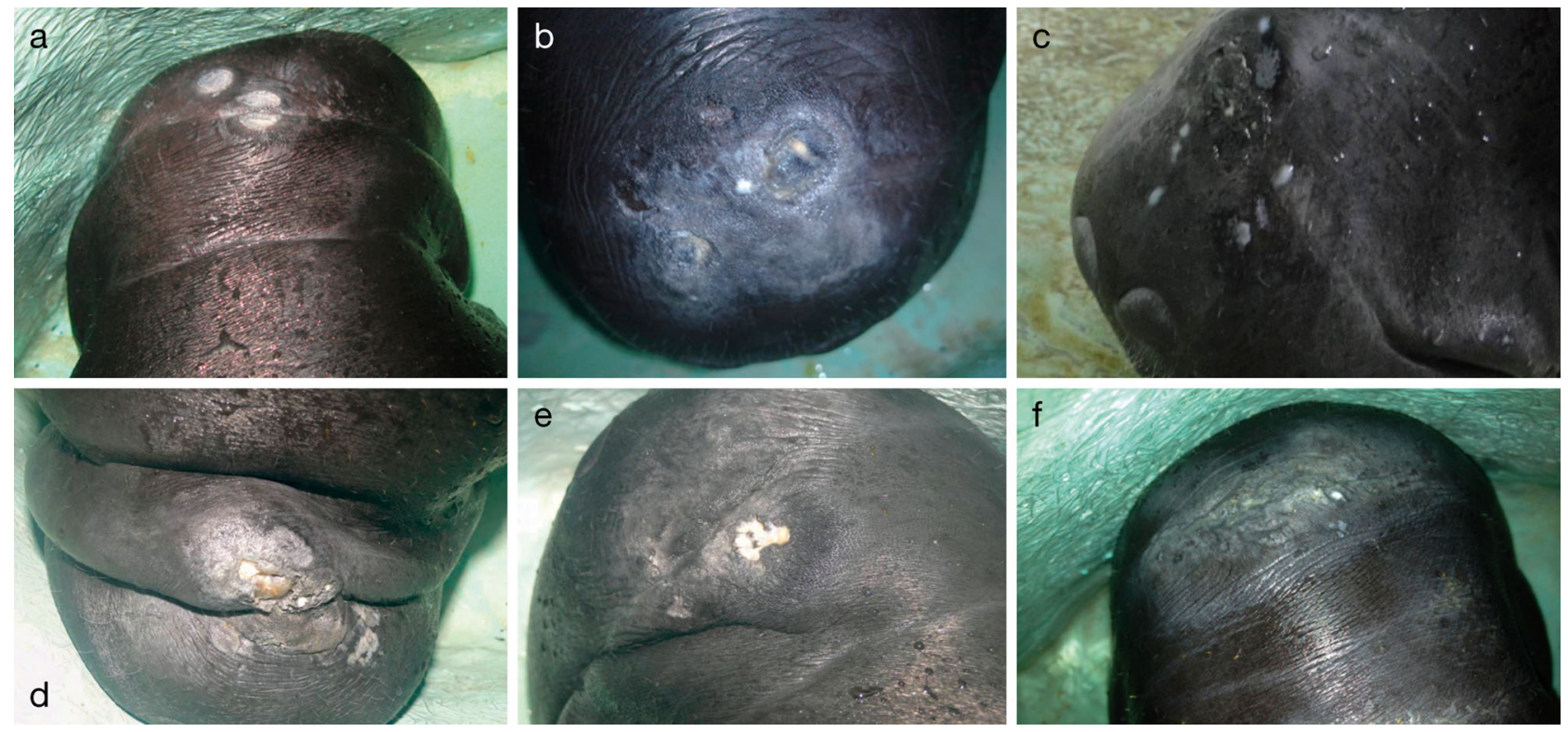

Fig. 1. Lesion progression in a captive adult male Amazonian manatee. (a) Three superficial hypopigmented circular skin lesions. (b) Four months after the first lesions were reported. Wound persistence can be observed. (c) Lesions presenting an increased volume (abscess). (d) General aspect of the lesions $2 \mathrm{~d}$ after drainage of the abscess. (e) General aspect of the lesions after $1 \mathrm{mo}$ of antibiotic therapy. (f) General aspect of the lesions after the end of treatment. The lesions are almost completely healed, but dry skin can be seen in the area

Fig. 1c). The animal presented with discomfort and withdrew when the area was touched. Skin temperature was increased compared to the rest of the body. The lesion was drained using a syringe and needle $(1.2 \mathrm{~mm} \times 40 \mathrm{~mm})$, and a skin biopsy from the abscess was performed with a $2 \mathrm{~mm}$ sterile punch (Fig. 1d). The drained abscess was flushed with sterilized $0.9 \%$ saline and $2 \%$ chlorhexidine solutions, followed by application of Rifamycin (Rifocina Spray, Aventis). Impression smears of the biopsy were prepared, and then the tissue was preserved in $10 \%$ buffered formalin, processed by conventional histologic techniques and embedded in paraffin. We then evaluated 3-5 $\mu \mathrm{m}$ hematoxylin and eosin sections by histopathology. Ziehl-Neelsen staining was performed on the impression smear, and cytology revealed pyogranulomatous infiltrates and numerous acid-fast bacilli. For bacterial speciation, samples of the abscess swab and skin biopsy were decontaminated with $0.75 \%$ cetylpyridinium chloride, inoculated into

Table 1. Complete blood count results from a captive adult male Amazonian manatee. Blood samples from August 2011 were collected during a routine check-up; lesions were first noted in November 2011. MCV: mean corpuscular volume; MCHC: mean cellular hemoglobin content. Reference values are from Lazzarini et al. (2014)

\begin{tabular}{|c|c|c|c|c|c|}
\hline Parameter & Aug 2011 & Nov 2011 & Mar 2012 & Sep 2012 & Reference range \\
\hline Red blood cells $\left(\times 10^{6} \mu \mathrm{l}^{-1}\right)$ & 2.3 & 2.3 & 2.9 & 2.7 & $2.54-3.20$ \\
\hline Hematocrit (\%) & 30 & 31 & 39 & 35 & $32.5-40.5$ \\
\hline Hemoglobin $\left(\mathrm{g} \mathrm{dl}^{-1}\right)$ & 9.0 & 10.1 & 12.5 & 11.6 & $10.2-12.8$ \\
\hline $\operatorname{MCV}\left(\mu m^{3}\right)$ & 130.43 & 134.78 & 134.48 & 129.63 & $117.2-139.6$ \\
\hline $\operatorname{MCHC}\left(\mathrm{g} \mathrm{dl}^{-1}\right)$ & 30.00 & 32.58 & 35.05 & 33.14 & $29.5-33.5$ \\
\hline Total protein $\left(\mathrm{g} \mathrm{dl}^{-1}\right)$ & 6.6 & 7.0 & 7.1 & 7.4 & $6.2-8.0$ \\
\hline Leukocytes (cells $\mu^{-1}$ ) & 8300 & 7900 & 10900 & 11000 & $5600-11000$ \\
\hline Heterophils (cells $\mu \mathrm{l}^{-1}$ ) & $3486(42 \%)$ & $3871(49 \%)$ & $4570(42 \%)$ & $3850(35 \%)$ & $2711-6279$ \\
\hline Lymphocytes (cells $\mu \mathrm{l}^{-1}$ ) & $4482(54 \%)$ & $3476(44 \%)$ & $5770(53 \%)$ & $6490(59 \%)$ & $1385-5300$ \\
\hline Monocytes (cells $\mu^{-1}$ ) & $332(4 \%)$ & $553(7 \%)$ & $545(5 \%)$ & $550(5 \%)$ & $125-580$ \\
\hline Eosinophils (cells $\mu^{-1}$ ) & $0(0 \%)$ & $0(0 \%)$ & $0(0 \%)$ & $0(0 \%)$ & $50-380$ \\
\hline Basophils (cells $\mu l^{-1}$ ) & $0(0 \%)$ & $0(0 \%)$ & $0(0 \%)$ & $110(1 \%)$ & $50-185$ \\
\hline Platelets (cells $\mu l^{-1}$ ) & - & - & - & - & $120-580$ \\
\hline
\end{tabular}


Stonebrink and Löwenstein-Jensen media and incubated at $37^{\circ} \mathrm{C}$. After $5 \mathrm{~d}$, acid-fast bacilli were isolated. Through PCR of the hsp65 gene, followed by restriction analysis of 2 enzymes, BstEII and HaeIII (PRA) (Telenti et al. 1993), the isolates were identified as Mycobacterium fortuitum and M. abscessus. No other significant pathogens were recovered by conventional microbiology, and complete blood counts showed an increased WBC count, at the high end of normal (11000 cells $\left.\mu \mathrm{l}^{-1}\right)$, due to a moderate lymphocytosis and an increase in monocyte numbers (high end of normal); biochemistry values were within normal reference limits for this species (Table 1) (Lazzarini et al. 2014).

The mycobacteriosis became a concern in terms of treatment options. Minimal inhibitory concentrations (MICs) of Mycobacterium isolates were determined by microdilution, as recommended by the Clinical and Laboratory Standards Institute (CLSI 2011), using Sensititre ${ }^{\mathrm{TM}}$ standard susceptibility MIC plates (RAPMYCO, TREK Diagnostic Systems/Thermo Fisher Scientific). The MICs demonstrated that $M$. fortuitum was more susceptible to ciprofloxacin, and $M$. abscessus to clarithromycin.

Oral administration of ciprofloxacin and clarithromycin (6 mg kg-1), once daily for $2 \mathrm{mo}$, was based on the antibiogram; in addition, ketoprofen (1 $\left.\mathrm{mg} \mathrm{kg}^{-1}\right)$ was given once daily for $7 \mathrm{~d}$, and ranitidine $(2 \mathrm{mg}$ $\mathrm{kg}^{-1}$ ) was administered once daily for 2 mo. Dosage was established by allometric scaling using a $168 \mathrm{~kg}$ placental mammal (manatee) as the target animal, and human dosage as the model (Pachaly 2007). To verify the dosage, our results were compared to available dosages for other mammals, such as horses and dogs. The same topical treatment was maintained 3 times a week.

The stress and logistics of physical restraint for intramuscular injections were limiting factors for using an injectable route. Due to the zoonotic potential of atypical mycobacteria, gloves were always used when handling the animal.

One month after beginning the treatment, an improvement was noticed (Fig. 1e), and after 2 mo of treatment, the lesion was resolved (Fig. 1f), and no alterations in the blood work were noted. Swabs of intact skin were collected for microbiology, and no mycobacterial growth was observed. Given the negative culture results and resolution of the skin lesion, antibiotic treatment was discontinued. Other intact skin swab samplings were cultured after 7 and 16 mo, and all results were negative for Mycobacterium spp. Despite the prolonged antibiotic treatment, the animal did not show any side effects.
During the whole period of this case, repeated environmental samples from water distribution pipes, tank water and the tank wall, as well as from 1 arapaima, 2 tambaqui and 5 redtail catfish, were submitted to the same mycobacterial culture. While some samples were negative, isolates of $M$. fortuitum and M. abscessus were recovered. Further characterization identified M. mucogenicum, M. chitae, M. phocaicum, M. bohemicum and $M$. neoaurum.

\section{DISCUSSION}

Mycobacterium fortuitum and $M$. abscessus are part of the rapidly growing NTM group. They are opportunistic pathogens found in water and soil, and infection can result in mycobacteriosis. Environmental exposure is expected, especially in aquatic animals, thus NTMs can be isolated from asymptomatic animals or without related disorders (Bercovier \& Vincent 2001).

Mycobacterial infections caused by $M$. marinum, $M$. fortuitum and $M$. chelonae are common in fish (Francis-Floyd 2011). Among aquatic mammals, $M$. marinum (Bowenkamp et al. 2001), M. chelonae (Wünschmann et al. 2008) and M. abscessus (Clayton et al. 2012) have been associated with clinical disease in cetaceans, whereas M. smegmatis (Gutter et al. 1987) and $M$. fortuitum (Lewis 1987, Wells et al. 1990) have been more frequently isolated from pinnipeds.

With regard to sirenians, $M$. chelonae (Boever et al. 1976) and $M$. marinum (Morales et al. 1985) infections have been observed in Amazonian manatees Trichechus inunguis, and $M$. marinum, $M$. fortuitum and $M$. kansasii were isolated from 2 Florida manatees T. manatus latirostris with clinical disease (Sato et al. 2003).

Clinical signs depend on the severity of infection and generally consist of anorexia (Bowenkamp et al. 2001, Wünschmann et al. 2008), lethargy, coughing, weakness, weight loss, respiratory discharge (Clayton et al. 2012), abnormal respiratory rate and loss of balance (Sato et al. 2003). In prior reports of mycobacteriosis in aquatic mammals, clinical disease generally started as chronic, nodular or vesicular/pustular skin lesions that ulcerated and/or developed to subcutaneous abscesses (Gutter et al. 1987, Wells et al. 1990, Bowenkamp et al. 2001). If inflammation was not resolved, infection could evolve to disseminated disease with caseonecrotic granulomas in the lungs, liver, kidney and/or lymph nodes, followed by death (Boever et al. 1976, Morales et al. 1985, Sato et al. 2003, Wünschmann et al. 2008, Clayton et al. 2012).

Boever et al. (1976) reported non-healing skin lesions in an Amazonian manatee, with no Myco- 
bacterium spp. isolates. Despite the systemic treatment with antibiotics, the animal died, and a diagnosis of mycobacteriosis was rendered post mortem (Boever et al. 1976). In the present case, the animal did not show systemic illness, and changes in appetite and weight were not observed during the clinical course of infection. Acid-fast staining methods, appropriate culture techniques and molecular testing played an important role in this case, especially to facilitate precise microbial identification, which was essential to establish an appropriate treatment protocol.

Immunosuppression may be considered an underlying cause in the development of mycobacterial infections (Thoen 2010). Usually, viruses, parasites and toxins may be predisposing factors; however, traumatic injuries to the skin may provide a portal of colonization and invasion with subsequent hematogenous dissemination. In this case, it is likely that the bacteria gained access to the skin secondary to a traumatic wound. M. abscessus and M. fortuitum can be recovered in large numbers in water distribution systems and aquaria, and biofilms may serve as an environmental reservoir and point source of these pathogens (Hall-Stoodley et al. 1998, September et al. 2004). A relationship between an environmental source of contamination and infection of this manatee could be demonstrated by recovery of both mycobacterial species from samples of the animal, incontact fish, water distribution pipes, tank water and the tank wall. A similar relationship was reported in a harbor seal case (Wells at al. 1990).

Mycobacteriosis due to $M$. chelonae and M. marinum is considered a significant pathogen in captive Amazonian manatees, with infection causing systemic disease, general debilitation and death. The main necropsy finding in affected animals was pyogranulomatous pneumonia (Boever et al. 1976, Morales et al. 1985). M. abscessus is resistant to most chemotherapeutics, and despite the susceptibility of $M$. fortuitum to some antimicrobials, it is still resistant to several others (Li et al. 2013). An effective treatment approach to rapidly growing mycobacterial infections requires administration of multiple antibiotics based on isolated bacterial susceptibility patterns.

Our clinical case was successful, probably due to an accurate diagnosis and microbial speciation that aided in a more targeted treatment strategy, which likely prevented further spread of the infection leading to systemic disease. Different bacterial strains as well as environmental conditions can also play an important role in determining the progression of the disease.
Mycobacteriosis in aquatic mammals is increasingly being diagnosed and may pose a public health concern (Waltzek et al. 2012). Since these bacteria are zoonotic, mycobacterial species from aquarium environments may infect not only aquarium fishes and aquatic mammals, but animal handlers as well (September et al. 2004). Several reports have described how aggressive and variable NTM infections can be in humans; infections may present as superficial granulomatous inflammation and may progress to involve deeper tissues (Piersimoni \& Scarparo 2009). Exposure of skin wounds, particularly abrasions, to contaminated water is usually the cause of human infections with mycobacterial pathogens of fish (Gauthier 2015).

Although treatment and control measures may include discard of infected animals and decontamination of holding facilities in aquaculture and ornamental aquaria (Gauthier 2015), NTMs are part of the environment (Hall-Stoodley et al. 1998, September et al. 2004). Therefore, mycobacterial re-infections will always be possible. This report recommends constant attention and monitoring of these microbes in display aquatic animals.

Acknowledgements. We thank all the keepers and interns from Aquário de São Paulo that were daily involved in the care of our manatee.

\section{LITERATURE CITED}

Bercovier H, Vincent V (2001) Mycobacterial infections in domestic and wild animals due to Mycobacterium marinum, $M$. fortuitum, $M$. chelonae, $M$. porcinum, $M$. farcinogenes, $M$. smegmatis, $M$. scrofulaceum, $M$. xenopi, M. kansasii, M. simiae and M. genavense. Rev Sci Tech Off Int Epizoot 20:265-290

*Boever WJ, Thoen CO, Wallach JD (1976) Mycobacterium chelonei infection in a natterer manatee. J Am Vet Med Assoc 169:927-929

Bowenkamp KE, Frasca S Jr, Draghi A II, Tsongalis GJ and others (2001) Mycobacterium marinum dermatitis and panniculitis with chronic pleuritis in a captive white whale (Delphinapterus leucas) with aortic rupture. J Vet Diagn Invest 13:524-530

Clayton LA, Stamper MA, Whitaker BR, Hadfield CA, Simons B, Mankowski JL (2012) Mycobacterium abscessus pneumonia in an Atlantic bottlenose dolphin (Tursiops truncatus). J Zoo Wildl Med 43:961-965

CLSI (Clinical and Laboratory Standards Institute) (2011) Susceptibility testing of Mycobacteria, Nocardiae, and other aerobic Actinomycetes; approved standard-2nd edn. CLSI document M24-A2. Clinical and Laboratory Standards Institute, Wayne, PA

Francis-Floyd R (2011) Mycobacterial infections of fish. SRAC Publication no. 4706. Southern Regional Aquaculture Center, Stoneville, MS. http://fisheries.tamu.edu/ 
files/2013/09/SRAC-Publication-No.-4706-MycobacterialInfections-of-Fish.pdf (accessed on 1 April 2015)

Gauthier DT (2015) Bacterial zoonoses of fishes: a review and appraisal of evidence for linkages between fish and human infections. Vet J 203:27-35

Gutter AE, Wells SK, Spraker TR (1987) Generalized mycobacteriosis in a California sea lion (Zalophus californianus). J Zoo Wildl Med 18:118-120

Hall-Stoodley L, Keevil CW, Lappin-Scott HM (1998) Mycobacterium fortuitum and Mycobacterium chelonae biofilm formation under high and low nutrient conditions. J Appl Microbiol 85(Suppl 1):60S-69S

IUCN (International Union for Conservation of Nature and Natural Resources) (2016) The IUCN Red List of Threatened Species. Version 2016-3. www.iucnredlist.org (accessed 30 October 2016)

Lazzarini SM, Vergara-Parente JE, Ribeiro DC (2014) Sirenia (Peixe-boi-da Amazônia e Peixe-boi-marinho). In: Cubas ZS, Silva JCR, Catão-Dias JL (eds) Tratado de animais selvagens, 2nd edn. Roca, São Paulo, p 936-972

Lewis JCM (1987) Cutaneous mycobacteriosis in a southern sea lion. Aquat Mamm 13:105-108

Li G, Lian LL, Wan L, Zhang J and others (2013) Antimicrobial susceptibility of standard strains of nontuberculous mycobacteria by microplate Alamar Blue assay. PLOS ONE 8:e84065,

Lightsey JD, Rommel SA, Costidis AM, Pitchford TD (2006) Methods used during gross necropsy to determine watercraft-related mortality in the Florida manatee (Trichechus manatus latirostris). J Zoo Wildl Med 37:262-275

Morales P, Madin SH, Hunter A (1985) Systemic Mycobacterium marinum infection in an Amazonian manatee. $\mathrm{J}$ Am Vet Med Assoc 187:1230-1231

Nielsen KA, Owen HC, Mills PC, Flint M, Gibson JS (2013) Bacteria isolated from dugongs (Dugong dugon) submitted for postmortem examination in Queensland, Australia, 2000-2011. J Zoo Wildl Med 44:35-41

Pachaly JR (2007) Terapêutica por extrapolação alométrica. In: Cubas ZS, Silva JCR, Catão-Dias JL (eds) Tratado de animais selvagens. Roca, São Paulo, p 1215-1223

Piersimoni C, Scarparo C (2009) Extrapulmonary infections associated with nontuberculous mycobacteria in immunocompetent persons. Emerg Infect Dis 15:1351-1358

Rosas FCW (1994) Biology, conservation and status of the

Editorial responsibility: Stephen Raverty,

Abbotsford, British Columbia, Canada
Amazonian manatee (Trichechus inunguis). Mammal Rev 24:49-59

Sato T, Shibuya H, Ohba S, Nojiri T, Shirai W (2003) Mycobacteriosis in two captive Florida manatees (Trichechus manatus latirostris). J Zoo Wildl Med 34:184-188

September SM, Brözel VS, Venter SN (2004) Diversity of nontuberculoid Mycobacterium species in biofilms of urban and semiurban drinking water distribution systems. Appl Environ Microbiol 70:7571-7573

Silva FMO, Marmontel M, Guterres-Pazin MG, Marsicano G, Suertegaray RR, Medeiros G, Ferraz MICP (2011) The healing process of skin lesions in a captive Amazonian manatee (Trichechus inunguis) calf: a case report. UAKARI 7:43-47

* Silva MC, Attademo FF, Freire AC, Sousa GP and others (2017) Identification of bacteria in blood cultures from clinically ill captive Antillean manatees (Trichechus manatus manatus). J Zoo Wildl Med 48:13-17

Silva VMF, Rosas FCW, Catanhede AM (2008) Peixe-boi da Amazônia, Trichechus inunguis (Natterer, 1883). In: Machado ABM, Drummond GM, Paglia AP (eds) Livro vermelho da fauna Brasileira ameaçada de extinção. Ministério do Meio Ambiente e Fundação Biodiversitas, Belo Horizonte, p 816-818

Sokolov VE (1982) Mammal skin. University of California Press, Berkeley, CA

Telenti A, Marchesi F, Balz M, Bally F, Böttger EC, Bodmer $\mathrm{T}$ (1993) Rapid identification of mycobacteria to the species level by polymerase chain reaction and restriction enzyme analysis. J Clin Microbiol 31:175-178

Thoen CO (2010) Tuberculosis and other mycobacterial diseases. In: Kahn CM, Line S (eds) Merck veterinary manual, 10th edn. Merck \& Co., Whitehouse Station, NJ, p 621-663

*Waltzek TB, Cortés-Hinojosa G, Wellehan JFX Jr, Gray GC (2012) Marine mammal zoonoses: a review of disease manifestations. Zoonoses Public Health 59:521-535

Wells SK, Gutter A, Van Meter K (1990) Cutaneous mycobacteriosis in a harbor seal: attempted treatment with hyperbaric oxygen. J Zoo Wildl Med 21:73-78

Wünschmann A, Armien A, Harris NB, Brown-Elliott BA and others (2008) Disseminated panniculitis in a bottlenose dolphin (Tursiops truncatus) due to Mycobacterium chelonae infection. J Zoo Wildl Med 39:412-420

Submitted: December 1, 2016; Accepted: November 23, 2017 Proofs received from author(s): February 1, 2018 